THIRD WMU INTERNATIONAL WOMEN'S CONFERENCE EMPOWERING WOMEN IN THE MARITIME COMMUNITY

\title{
Beyond Business-As-Usual:
}

The role of women professionals in maritime clusters 


\section{Setting the Scene..}

- What's the results after $\mathbf{3 0}$ years of IMO IWMS?

- We are still not there..

- Progress at snail's pace..

- Education empower women to join the maritime industry, how to integrate them?

- Women still mainly at operational level? How to get them to the decision-making level?

- Shift from UN MDG 3 (2000 - 2015) : Promote gender equality and empower women to SDG 5 (20152030) Achieve Gender Equality and empower all women and girls? What's the difference?.. 


\section{CONTEXT}

- Ref: WMU Women Conferences

$\checkmark$ Empowering professional women in the maritime world (2008)

$\checkmark$ Maritime Women - Global leadership (2014)

$\checkmark$ Empowering Women in the Maritime Community (2019)

* This paper examines the relevance of gender with respect to the concept of maritime clusters. 


\section{CONCEPTUAL FRAMEWORK}

Maritime Clusters

This paper examines the relevance of gender with respect to the concept of maritime clusters which has gained popularity from Wa strategic economic development perspective in increasing overall efficiency of the industry through innovation.

The original concept of "cluster" has been developed by Michael Porter who defines as a geographically proximate group of interconnected companies and associated institutions in a particular field, linked by commonalities and complementarities' 


\section{CONCEPTUAL FRAMEWORK}

The maritime sector is very broad, composed of organisations and activities such as maritime transportation, port services and logistics, naval architecture (naval engineering, ship-building ship-repair companies, and the component supply sector), financial services, legal and accounting services, classification, marine insurance providers, commercial fishing and aquaculture industry, the cruise and recreational sector, sport and marinas, marine energy sources, navies, marine and ocean research and sciences, maritime training academies and training centres, a wide range of professional services around the maritime activities, and professional associations, trade unions and organisations supporting the rights and interests of seafarers and maritime professionals (Lambrou, 2016). 


\section{METHODOLOGY}

Rapid Integrated Assessment (RIA) :

$\checkmark$ Methodology initially developed to facilitate mainstreaming of

SDGs into national and local plans-adapted to the maritime sector to prioritise gender based interventions through maritime clusters

\section{Selected Countries:}

Japan, Norway, Singapore with respect to their respective success in establishing solid maritime industrial outputs in different manners 


\section{METHODOLOGY}

\section{Rapid Integrated Assessment (RIA) :}

$\checkmark$ Step 1 is to analyse the relevance of the SDGs for the country in terms of their national and subnational development priorities, and to map SDG targets within the development and sectoral plans.

$\checkmark$ Step 2 is to understand how the focus of SDG targets are balanced within three dimensions of sustainable development (social, economic and environment) as well as across the 5P's (people, planet, prosperity, peace and partnership).

$\checkmark$ Step 3 involves in assessing existing monitoring capacity with a checklist for conducting a needs assessment.

$\checkmark$ Step 4 is a consolidation of the primary outputs to identify challenges and gaps in their national/subnational plans. 


\section{KEY FINDINGS}

\section{Japan}

\begin{tabular}{|c|c|c|}
\hline Summarised RIA Results & National priorities & $\begin{array}{c}\text { Maritime cluster } \\
\text { priorities }\end{array}$ \\
\hline $\begin{array}{l}\text { Japan's gender gap is } \\
\text { extremely large in the } \\
\text { labour market in terms of } \\
\text { wage, employment type, } \\
\text { and career progression. } \\
\text { Among OECD countries, } \\
\text { Japan shows the highest } \\
\text { gender gap in ICT-based } \\
\text { problem-solving skills . } \\
\text { Needs assessment in the } \\
\text { maritime sector will assist a } \\
\text { better understanding of } \\
\text { necessary interventions. }\end{array}$ & $\begin{array}{l}\text { - Supporting job } \\
\text { access by female } \\
\text { non-working } \\
\text { population who } \\
\text { wish to work } \\
\text { - Promoting women } \\
\text { in leadership } \\
\text { positions } \\
\text { - Preventing } \\
\text { harassment related } \\
\text { pregnancy, } \\
\text { childbirth and } \\
\text { childcare leave }\end{array}$ & $\begin{array}{l}\text { Expansion of existing } \\
\text { maritime clusters to new } \\
\text { industries, such as ocean } \\
\text { development (i.e., oil, } \\
\text { LNG), alternative energy } \\
\text { source (i.e., shale gas, } \\
\text { hydrogen), and marine } \\
\text { renewable energy (i.e., } \\
\text { wind, wave, tidal, and } \\
\text { current) }\end{array}$ \\
\hline
\end{tabular}




\section{KEY FINDINGS}

\section{Norway}

\begin{tabular}{|c|c|c|}
\hline Summarised RIA Results & National priorities & Maritime cluster priorities \\
\hline $\begin{array}{l}\text { Norway is one of the world } \\
\text { leaders in digitization and } \\
\text { automation in the maritime } \\
\text { industry, however in core ICT } \\
\text { skills, for example, } \\
\text { programming skill in Norway } \\
\text { is reported as one of the } \\
\text { highest gender gaps at a } \\
\text { global level [10]. Ensuring } \\
\text { gender equality in digitization } \\
\text { seems to be important for the } \\
\text { maritime cluster in Norway. }\end{array}$ & $\begin{array}{l}\text { - Combating gender } \\
\text { segregation in the } \\
\text { labour market and } \\
\text { involuntary part- } \\
\text { time employment. } \\
\text { - Greater inclusion of } \\
\text { women from ethnic } \\
\text { minorities in the } \\
\text { labour market. } \\
\text { - Combating violence } \\
\text { and sexual abuse. }\end{array}$ & $\begin{array}{l}\text { - Collaborative } \\
\text { innovation; Knowledge } \\
\text { linkages; } \quad \text { Cluster } \\
\text { development; Cluster- } \\
\text { to-cluster . }\end{array}$ \\
\hline
\end{tabular}




\section{KEY FINDINGS}

\section{Singapore}

\begin{tabular}{|c|c|c|}
\hline Summarised RIA Results & National priorities & Maritime cluster priorities \\
\hline $\begin{array}{l}\text { Women in leadership } \\
\text { positions are generally low } \\
(\mathbf{1 0 - 1 2 \% ) .}\end{array}$ & $\begin{array}{l}\text { - Increasing } \\
\text { representation on } \\
\text { boards . } \\
\text { - Stimulating workforce } \\
\text { participation by } \\
\text { women and removing } \\
\text { work-life imbalances } \\
\text { and challenges } \\
\text { Removing potential } \\
\text { retirement inadequacy } \\
\text { of women }\end{array}$ & $\begin{array}{l}\text { Water conservation (e.g., } \\
\text { removal of pollutants from } \\
\text { rivers, awareness raising } \\
\text { through education). } \\
\text { - } \quad \text { Space optimization (i.e., } \\
\text { relocation of maritime } \\
\text { ports and other facilities) } \\
\text { - Reduction of maritime } \\
\text { transport emissions } \\
\text { Promotion of green } \\
\text { technology } \\
\text { Energy-efficient maritime } \\
\text { transport technologies }\end{array}$ \\
\hline
\end{tabular}




\section{CONCLUSION}

- Not a comparative analysis

- Simple and systematic approach to identify gaps in developing and implementing gender based strategies

- An attempt to demonstrate the potential 'means' (maritime cluster) to the aspired 'ends' (women empowerment)

- Limitations:

- Desktop Research

- Information gathered mainly from online sources 


\section{CONCLUSION}

- RIA is a potential tool for profiling of countries' success towards women empowerment in the maritime sector

- The outcomes of the proposed methodology provide a baseline to build on effective interventionist strategies gender based in the applicable context

- It also allows ease of identifying best practices to be emulated 


\section{WAY FORWARD}

- Existing interventions are critical, nonetheless their impact seem to remain palliative ..

- Action speaks louder than words

e.g. UNOPS' initiatives towards the development of gender sensitive infrastructure is commendable but how do we ensure that this facility is adopted by the key players of the industry? How to secure their engagement? 


\section{WAY FORWARD}

- Shift from policy to institutional reforms

- The systems connects the dots from policy to people

\section{Women \\ Empowerment}

Policy

\section{Institutions}




\section{WAY FORWARD}

Foreseeing the Fourth Industrial Revolution or Industry 4.0 as well as emerging business models in the maritime industry, gender equality is an opportunity to go beyond business-as-usual and advance sustainable development in the maritime sector.

UN Women (2018) notes that achieving the ambitious 17 goals of the United Nations 2030 Agenda for Sustainable Development 'requires transformative shifts, integrated approaches and new solutions, particularly when it comes to advancing gender equality and the empowerment of all women and girls' 


\section{WAY FORWARD}

McKinsey Global Institute (2015) estimates that if women participate in the economy at the same level as men - in their "full-potential" scenario, it would add up to \$28 trillion, or 26 per cent, to annual global GDP by 2025 compared with a business-as-usual scenario.

NOW is the time to go beyond business as usual ..

So, together let's chart an inclusive and incredible maritime community! 


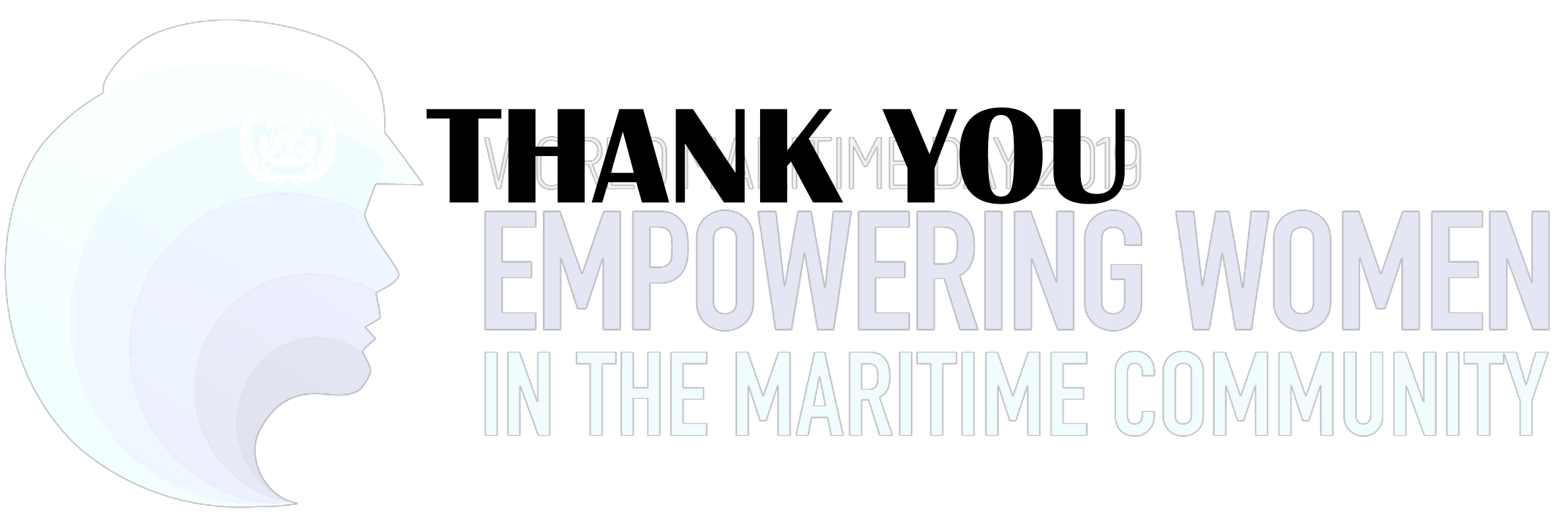

KITADA, M. \& BHIRUGNATH-BHOOKHUN, M. 